\title{
Does financial inclusion empower women in emerging countries? A panel data analysis
}

Chandan Kumar Roy ( $\square$ chandan_hstu@yahoo.com )

Bangladesh Bank https://orcid.org/0000-0003-3681-8771

Banna Banik

Bangladesh Bank

Huang Xiaoling

School of International Trade and Economics, University of International Business and Economics

Research

Keywords: Financial inclusion, Women empowerment, Gender inequality, Emerging countries

Posted Date: May 6th, 2020

DOI: https://doi.org/10.21203/rs.3.rs-26363/v1

License: () (1) This work is licensed under a Creative Commons Attribution 4.0 International License. Read Full License 


\section{Abstract}

Women empowerment is inevitable and a fundamental goal for inclusive growth and sustainable development. The study aims to analyze the effect of financial inclusion on women empowerment using both fixed-effects and panel generalized methods of moments (GMM) estimation techniques covering a panel dataset of 50 emerging economies from 2005 to 2017 . We use accessibility to automated teller machine services, availability of bank branches and accessibility to bank assets as three different measures of financial inclusion and gender inequality index, gender development index and political participation of females as the measure of women empowerment. We find evidence that each measure of financial inclusion is associated with lower gender inequality, higher gender development and more opportunities for political involvement of women respectively. Using different econometric estimation method and a board range of inclusion measures confirms the more robust association between financial inclusion and women empowerment. The study, thus, concludes that financial inclusion plays an important role in the welfare of female and girls which would further assist emerging economies to achieve Sustainable Development Goal 5.

\section{Background}

Women's empowerment through financial inclusion becomes a cross-cutting issue of discussion among the international development organizations, policymakers and researchers as studies found the persistent presence of gender gap in financial inclusion.

Representing "gender equality and empower all females" in 2030 SDG agenda makes this topic more significant. In developing nations, gender inequality in access to banking services is still high. More than half of the unbanked populations in the world are women. $67 \%$ of men have a formal account with the banks and financial institutions whereas $59 \%$ of the female have access to an account. Since 2011, this gap almost remains constant which is consistently more than $8 \%$ (Demirgüç-Kunt et al. 2018). Moreover, girls and females are still facing various economic, social and political limitations and obstacles. They have lower labor force participation rate, lower access to financial services, lower enrollment and compilation rate of education, and lesser rate of political participation. Women spend a larger proportion of their time in the household works and child care than men. In some societies, females are the targets of many violent activities. Employed women are also facing persistent gender-based inequity at their workplace including a greater gender wage gap. These types of inequalities have both social and economic costs including losses of working productivity, higher health care, and legal expenses. Minimizing gender disparities and improving women's welfare is extremely crucial not only for social and moral aspects but also from an economic development standpoint. Full access to financial products and services is a policy tool for women's full participation in the economy and more inclusion of females in the economy would lead to benefits in the growth of GDP (IFC, 2016). Enhanced and easier access to financial credit facilities help women entrepreneurs to increase the productivity of the enterprise, managerial capacity, and more profits. Women's additional income allows them to save, further productive investment and more consumption (World Bank/OECD, 2013) which facilitates efficient allocation of resources within households that leads to an increase in family expenditure to health care, child nutrition and education (Castilla and Walker, 2013).

Financial inclusion refers to a circumstance in which individuals and businesses, including those currently excluded from the formal banking system, have access to effective financial products and services that meet their needs such as access to credits, daily transactions, savings, and deposit transactions and insurance (AFI, 2016). This is one of the important and proven regulatory instruments to increase macroeconomic welfare, enhance stability, and reduce poverty and inequality (Beck et al. 2007; Cull et al. 2012; Kim 2016). Participation on financial services, particularly access to accounts, helps individual to start a new business and expand an existing one, encourages more investment in schooling and health, and increases savings and consumption which have a greater impact on reducing income inequality, rapid economic growth and women empowerment (Isaac 2014)

Thus, this study investigates the main research question-does financial inclusion (FI) empowers women? Besides, this study also analyzes- what is the major contribution of different indicators of $\mathrm{Fl}$, such as access to banks, access to ATMs and access to credit facilities, on enhancing women empowerment and how these indicators could help to achieve SDG 5? This study uses the gender inequality index (GII) as the outcome variable because it measures three major dimensions at the same time such as political engagement, participation rate to the labor force and mortality rate. Lower the value of GII implies lower the gap between males and female which in turn means high women empowerment. Covering panel data of 50 developing countries from 2005-2017, this study finds that more access to banks, ATMs and credit facilities are negatively associated with gender inequality. The results are highly statistically significant and robust to both fixed effects and generalized method of moment estimation technique. This study also considers the gender development index (GDI) and women's political empowerment as the dependent variable instead of GII. 
Employing fixed effects estimation confirms that FI helps to improve GDI and also increases the opportunity of the political empowerment of females.

This study contributes to the literature in the following three ways. First, the study uses three important proxy indicators of financial inclusion, such as access to banks, access to ATMs and access to banks services and analyzes their impact mainly on reducing gender disparities. This would be the pioneering study to investigate such results in the developing economy perspective. Second, most of the existing papers related to financial inclusion and women's development are based on theoretical perspective and case study. Numerous numbers of literatures are related to financial inclusion and economic growth. An empirical study on women empowerment through financial inclusion is still untouched and has a potential scope of the profound investigation. Third, the study considers three dependent variables that represent women empowerment in a single econometric specification using the latest available annual panel data till 2017, applies both static and dynamic panel data estimation techniques and controls country-specific heterogeneity, endogeneity, and autocorrelation. These techniques provide more robust findings and offer a strong basis for evidence-based policymaking on financial inclusion which helps to promote women empowerment in developing countries.

The remaining part of the study is arranged as follows. Section 2 analyzes existing literature on financial inclusion and women empowerment. Section 3 methodology and data. Section 4 discusses the sources of data and several stylized facts related to our study. Section 5 and 6 present the results and discussion and robustness tests, respectively, while 7 concludes the paper with some policy implications.

\section{Literature Review}

The impact of indicators of financial inclusion on women empowerment is still unclear due to the limitation of gender centric disaggregated data as well as fewer empirical studies. Numerous reports and case studies state the descriptive background through which financial inclusion could reduce the gender gap and increase women's participation in the economy. But very few empirical studies are available on nexus between these two macroeconomic factors. At the very beginning, several studies have been conducted on nexus between women's access to credit facilities, particularly access to micro-finance, and gender inequality. But findings from those studies are still controversial. Studies by Cheston and Kuhn 2002, Khandker 2005 and Armendáriz and Morduch 2010 concluded that microfinance empowering women by reducing gender inequality. Easier access to micro-credit facilities would support women's decision making ability and strengthen their bargaining power within the family (Alam 2012). Individual country-level study on the impact of group-based micro-credit programs (both men and women) on different measures of women empowerment was conducted by Pitt et al. (2006) on Bangladesh and Swain and Wallentin (2009) for India and their findings are positive and significant to female empowerment. Some studies found a conditional relationship between female's access to credit facilities on their empowerment and equality with men. The positive effects of microfinance are not automatic and conditional to the level of education of female borrowers and the purposes of the lenders (Kabeer 2005). Mahmood (2011) stated that gender equality through microfinance can be achieved if the female has proper business-related training for which she borrows the loans. It also depends on the social and cultural beliefs, norms and autonomy of using the funds. Without these things female has the chance to lose possession of her fund by men which in turn increase gender inequality.

But the scope of financial inclusion is not limited to micro-credit facilities. Fl is converted to the national goal and international strategy for sustainable development and access to credit is a means of Fl. Only a limited number of investigations carried out whether $\mathrm{Fl} \mathrm{help}$ to improve human lives and empowers women. Ashraf et al. (2010) try to find out the impact of saving products on female empowerment in the Philippines. Using a randomized controlled trial method they find that female's decision making power within the household (such as what to buy, family purchases, recreational expenses, personal expenses, the decision of family planning, children education, etc) is positively affected by the female who has access to commitment saving products of banks. Dupas and Robinson (2013) also use the same approach to measure the effect of access to basic savings products of financial institutions on two types of self-employed rural people in Kenya. The treatment group includes market vendors mostly owned by women and the control group includes bicycle taxi drivers owed by the male. Applying the difference-in-differences method of estimation they find that access to the savings account has no impact on the male group. Despite various bank's fees, access to saving products has a positive effect on women's group by saving more, encouraging private investment and personal expenditures. Zhang and Posso (2019) conduct a study on the impact of financial inclusion on 6200 Chinese household income. They find that financial inclusion positively associated with the income of households. This positive impact is more effective in the household with low-income level than that of mid and highincome level household and thus, financial inclusion assists to decline income inequality among the Chinese families. A large body of 
literature such as Kim et al. (2018), Nwafor and Yomi (2018), Sharma (2016), Sahay et al. (2015), Onaolapo (2015), and Kpodar and Andrianaivo (2011) also investigates the impact of financial inclusion on economic growth. They conclude financial inclusion is one of the key policy tools that facilitate inclusive growth of the economy. Economic growth would help to increase the empowerment of women but their studies do not focus on any female or gender-related outcomes.

\section{Methodology And Data}

\subsection{Methodology}

This study employs several alternative methodologies, such as OLS, Fixed Effects and Generalized Methods of Moment (GMM) estimation techniques to determine the effect of the different indicators of financial inclusion on women empowerment. The baseline econometric specification for the study is:

$$
\begin{aligned}
G I I_{i t}=\alpha_{0}+ & \gamma l n F I_{p, i t}+\phi_{1} L F_{i t}+\phi_{2} N R R_{i t}+\phi_{3} \operatorname{CON}_{i t}+\phi_{4} D C_{i t}+\phi_{5} T F_{i t}+\phi_{6} G D P_{i t} \\
& +\eta_{i}+\lambda_{t}+\varepsilon_{i t}
\end{aligned}
$$

Where, $\mathrm{Gl}_{\mathrm{it}}$ is the Gender Inequality Index, the proxy of women empowerment for country $i$ in year $t$. InFI $\mathrm{p}_{\mathrm{p}, \mathrm{t}}$ refers to the natural log of financial inclusion measures, $p$. LF = percentage of female labor force of total labor force, NRR = natural resources rent percentage of GDP, CON = household consumption, $T F=$ trade freedom score, GDP = Annual growth of Gross domestic product. $\eta_{i}$ represents country fixed effect, $\lambda_{t}$ indicates the time effects, and $\varepsilon_{i t}$ is the residual term that also captures the effect of all unobserved omitted variables. The result of the Hausman specification test signifies that the fixed effects model is more appropriate than the random-effects model. As a result, panel fixed effects estimation results are reported directly in this paper.

Moreover, there is a possibility to arise the debate that all independent variables exploit in our fixed effects model are not rigorously exogenous. A model that allows controlling for the endogeneity of independent variables, serial autocorrelation, and heterogeneity through the use of lagged dependent variable and internal instruments is the Arellano and Bond (1991) difference GMM estimator. The study also employs the difference GMM estimation of our baseline model. Two appropriate post estimation tests, test for second-order correlation in the first differenced residuals (the Arellano-Bond test) and test for over-identifying restrictions (the Hansen and Sargan Test) are carried out on the difference GMM estimation. Therefore, the specification for difference GMM estimator is-

$$
\begin{aligned}
G I I_{i t}=\alpha \Delta G I I_{i t-1}+\gamma \Delta l n F I_{p, i t}+\phi_{1} \Delta L F_{i t}+\phi_{2} \Delta N R R_{i t}+\phi_{3} \Delta C O N_{i t}+\phi_{4} \Delta D C_{i t} \\
+\phi_{5} \Delta T F_{i t}+\phi_{6} \Delta G D P_{i t}+\Delta \varepsilon_{i t}
\end{aligned}
$$

This study also uses different measures of women empowerment, such as gender development index (GDI) and women political empowerment (the proportion of parliamentary seat held by female), as dependent variable instead of gender inequality index (GII) and employ the panel fixed effects model to check the robustness of results of the baseline model.

\subsection{Definition and sources of data}

The data on financial inclusion were collected from the Financial Access Survey (FAS) dataset of the International Monetary Fund (IMF). The G20 Financial Inclusion Indicators formally declared nine indicators from the IMF FAS survey as financial inclusion indicators. This study uses three major indicators of financial inclusion as our main explanatory variable of interest (Sahay et al. 2015 and Kim et al. 2018). The study is expecting indicators of financial inclusion have a negative impact on the gender inequality index and positive effect on both gender development index and women's political empowerment. The indicators of financial inclusion include-

1. Access to Automated Teller Machine (ATM) which refers to the total number of ATMs per 0.1 million people,

2. Access to commercial bank branches which refers to the total number of commercial bank branched per 0.1 million people and

3. Access to loan facilities which refers to the total outstanding loans from commercial banks (\% of GDP).

The main dependent variable of this study is the Gender Inequality Index (GII) used as a proxy of women empowerment and the data on GII were collected from the United Nations Development Program (UNDP) dataset. The GII, indexed from minimum 0 to maximum 1, measures the potential gap between women and men in three aspects- reproductive health, empowerment both political and 
educational, and participation in the labor force. The higher the index signifies higher the disparities between males and female which implies lower women empowerment. The alternative dependent variables used in this analysis are the Gender Development Index (GDI) and Women Political Empowerment. GDI also scales from 0 to 1, and it is assumed that positive and higher the GDI women are highly empowered. Data on GDI and political empowerment are collected from UNDP and WDI database. The study converts the scale of measuring GII and GDI from index 0-1 to 1-100.

The important control variables include female labor force percentage of the total labor force (LF), domestic credit to the private sector (DC), GDP growth, natural resources rent over GDP (NRR) and household consumption (CON), were obtained from World Development Indicators (WDI) of World Bank Database. Data on trade freedom (TF) were collected from the Heritage Foundation. The coefficient of the variable female labor force, domestic credit to the private sector, trade freedom and GDP growth are expected to have a negative effect on GIl as more entry of female labor to the total labor market, more access to loans, more freedom to international trade and higher the GDP growth is associated with higher women empowerment thus reduce inequality between men and female. The coefficients of NRR and CON are expected to have a positive effect as more men are engaged in renting natural resources than females (Tang and Zhang 2014) and, later on, the family and social system are not willing to spend more on women health and education.

This study considers a balanced panel dataset that consists of a total of 50 developing countries from the year 2005 to 2017 . The countries are selected on the basis availability of the secondary data. The list of emerging countries and detail of data definition and sources taken for this study are listed in Appendix A and Appendix B respectively. In Table 1, the descriptive statistics of the data are reported. The total number of observations is 650 .

The correlation matrix, presented in Table 2, check out the pattern of relationships between the variables that the study considers for analysis. The gender inequality index is found to be negatively correlated with indicators of financial inclusion and significant at the $10 \%$ level. Domestic credit and freedom to international trade are significantly and negatively correlated with the Gll. Household consumption expenditure is positively and significantly correlated with gender disparities. However, the VIF test shows the meanvariance inflation factor (VIF) is 1.65, 1.46 and 2.73 respectively using access to ATMs, access to branches and access to loans separately in the regression (Appendix $\mathrm{C}$ ) implying that the empirical estimates in this study can hardly be affected by multicollinearity problem as VIF value does not exceed 4.0 (Hair et al. 2010).

Table 1

Summary Statistics

\begin{tabular}{|lllllll|}
\hline Variables & Notation & Observations & Mean & Std. Dev. & Min & Max \\
\hline Gender Inequality Index & GI & 650 & 45.35021 & 11.7138 & 15.2 & 73.24 \\
\hline Gender Development Index & GDI & 650 & 92.18477 & 6.73967 & 66.3671 & 102.7 \\
\hline Women Political Empowerment & PEmp & 650 & 20.67016 & 11.66581 & 2.8 & 63.8 \\
\hline Access to ATMs & InATMs & 650 & 2.625669 & 1.386806 & -4.42502 & 4.781105 \\
\hline Access to Bank Branches & InBranches & 650 & 2.142625 & 0.921372 & -0.78966 & 4.271194 \\
\hline Access to loans & InLoans & 650 & 35.64091 & 21.56516 & 6.285613 & 116.1229 \\
\hline Female Labor Forces & LF & 650 & 40.62618 & 9.346549 & 14.38434 & 54.99547 \\
\hline Natural Resources Rent & NRR & 650 & 7.190789 & 8.231793 & 0.001133 & 45.5739 \\
\hline Domestic Consumption & CON & 650 & 83.5338 & 14.573 & 41.9307 & 117.632 \\
\hline Domestic Credit & DC & 650 & 42.72245 & 31.98849 & 5.0483 & 160.125 \\
\hline Trade Freedom & TF & 650 & 73.134 & 10.19031 & 24 & 89.2 \\
\hline GDP Growth & GDP & 650 & 4.667222 & 3.617642 & -14.7585 & 34.5 \\
\hline
\end{tabular}


Table 2

Correlation matrix for baseline model variables

\begin{tabular}{|c|c|c|c|c|c|c|c|c|c|c|}
\hline Variables & GII & InATMs & InBranches & InLoans & LF & NRR & CON & DC & TF & GDP \\
\hline GII & 1.0000 & & & & & & & & & \\
\hline InATMs & $-0.6392^{\star}$ & 1.0000 & & & & & & & & \\
\hline InBranches & $-0.5381^{\star}$ & $0.6529 *$ & 1.0000 & & & & & & & \\
\hline InLoans & $-0.4981^{*}$ & $0.5164^{*}$ & $0.3759 *$ & 1.0000 & & & & & & \\
\hline LF & -0.0149 & $-0.1299 *$ & $-0.3473^{\star}$ & $-0.2466^{\star}$ & 1.0000 & & & & & \\
\hline NRR & 0.0677 & $-0.2147 *$ & $-0.1054^{\star}$ & $-0.2227 *$ & 0.0194 & 1.0000 & & & & \\
\hline CON & $0.1897 *$ & -0.2410 * & -0.1002 & $-0.2483^{\star}$ & $0.2707 *$ & $-0.4442^{\star}$ & 1.0000 & & & \\
\hline DC & $-0.4746^{\star}$ & $0.5284^{*}$ & $0.3222^{*}$ & $0.8980 *$ & $-0.1174^{\star}$ & $-0.2056^{\star}$ & $-0.2865^{\star}$ & 1.0000 & & \\
\hline TF & $-0.3634^{\star}$ & $0.5169 *$ & $0.2856^{\star}$ & $0.2091^{*}$ & $0.2685^{\star}$ & $-0.2049 *$ & $0.1565^{\star}$ & $0.1951^{*}$ & 1.0000 & \\
\hline GDP & 0.0832 & -0.2026 * & -0.062 & -0.0841 & 0.0953 & $0.1866^{\star}$ & $-0.2110 *$ & -0.0848 & $-0.1240 *$ & 1.0000 \\
\hline
\end{tabular}

\section{Stylized Facts Supporting Testable Hypothesis}

Figure 1, Fig. 2 and Fig. 3 respectively illustrate the co-movement of different indicators of financial inclusion with GII and GDI. Essentially, Fig. 1 illustrates the movement of peoples' access to the number of ATMs with GII and GDI while Fig. 2, people's access to bank branches with GII and GDI. Finally, Fig. 3 displays an association of access to the use of bank loans with GII GDI. The figures consistently illustrate a negative relationship between financial inclusion indicators on GII is visible. On the contrary, evidence of positive co-move between financial indicators and GDI is noticeable. Such opposite co-movement may be most significant between financial inclusion and GII. Intuitively, a high level of financial inclusion initiatives would associate with the lower values of gender disparities and higher values of gender development in developing countries. The study endeavors to confirm this understanding with the econometric specification with additional control variables in the empirical section. The subsequent key hypothesis to be verified in this study is the following-

H0: There is no effect of financial inclusion on reducing gender disparities between male and female through access to ATMs, access to bank branches and access to bank loans program.

$\mathrm{H} 1$ : There is a significant effect of financial inclusion on reducing gender disparities between male and female through access to ATMs, access to bank branches and access to bank loans program.

\section{Results And Discussion}

The preliminary assessment is employed using OLS and panel fixed effects model. All the variables are in percentage form except GII and trade freedom index. Table 3 illustrates the results using these two methods. The results in this table validate the main hypotheses that higher the access to ATMs, bank branches and loan facilities in a country the lower is the disparities between male and female, ceteris paribus. All three indicators of financial inclusion have a negative coefficient and in every case are strongly statistically significant at a $1 \%$ level. Panel data estimation using OLS could raise bias results because of omitted variables and unobserved country characteristics. The fixed-effects model can control this unobserved heterogeneity, thus our discussion is mainly based on fixed effects estimation. Moving from column 4 to column 6, the fixed effects estimation results shows that (1) a one percent increase in banks ATMs decreases GII by 2.61 points, (2) a one percent raise of bank branches cut GII by 3.37 points and (3) a unit percent increase of people's access to bank loans reduce Gll by 0.19 points, ceteris paribus. This means that more access to saving and checking accounts for any formal and informal financial transaction through automated teller machines, deposit machines, bank branches or mobile banking encourages more savings; investment and household consumption empower the women. Access to bank loans and advances affects consumption patterns positively, generates more income and employment opportunities for women that would help to reduce the gender gap in the developing countries. These enhanced financial inclusion initiatives including financial 
literacy programs encourage women's labor force participation; develop entrepreneurship, helping to set up new SMEs and boost inclusive growth (IMF 2018).

Table 3 Panel analysis, OLS and Fixed-Effects

Dependent Variable: Gender Inequality Index

\begin{tabular}{|c|c|c|c|c|c|c|c|c|c|}
\hline VARIABLES & $\begin{array}{c}(1) \\
\text { OLS }\end{array}$ & $\begin{array}{l}(2) \\
\text { OLS }\end{array}$ & $\begin{array}{l}(3) \\
\text { OLS }\end{array}$ & $\begin{array}{l}(4) \\
\mathrm{FE}\end{array}$ & $\begin{array}{l}\text { (5) } \\
\mathrm{FE}\end{array}$ & $\begin{array}{l}6) \\
\mathrm{FE}\end{array}$ & $\begin{array}{c}\text { (7) } \\
\text { FE-Year }\end{array}$ & $\begin{array}{c}(8) \\
\text { FE-Year }\end{array}$ & $\begin{array}{c}\text { (9) } \\
\text { FE-Year }\end{array}$ \\
\hline \multirow{2}{*}{$\begin{array}{l}\text { Access to } \\
\text { ATMs }\end{array}$} & $-4.715 * * *$ & & & $-2.611 * * *$ & & & $-0.910 * * *$ & & \\
\hline & $(0.370)$ & & & $(0.207)$ & & & $(0.231)$ & & \\
\hline $\begin{array}{l}\text { Access to } \\
\text { Branches }\end{array}$ & & $-5.981 * * *$ & & & $-3.367 * * *$ & & & $-0.985 * *$ & \\
\hline & & $(0.442)$ & & & $(0.473)$ & & & $(0.422)$ & \\
\hline $\begin{array}{l}\text { Access to } \\
\text { Loans }\end{array}$ & & & $-0.216 * * *$ & & & $-0.185^{* * *}$ & & & $-0.117 * * *$ \\
\hline & & & $(0.0427)$ & & & $(0.0386)$ & & & $(0.0313)$ \\
\hline $\begin{array}{l}\text { Female Labor } \\
\text { Force }\end{array}$ & $-0.114^{* * *}$ & $-0.281 * * *$ & $-0.112^{* *}$ & $-0.768 * * *$ & $-0.794^{* * *}$ & $-0.706 * * *$ & $-0.306 * * *$ & $-0.257 * *$ & $-0.192 *$ \\
\hline & $(0.0411)$ & $(0.0443)$ & $(0.0478)$ & $(0.114)$ & $(0.123)$ & $(0.127)$ & $(0.106)$ & $(0.106)$ & $(0.105)$ \\
\hline $\begin{array}{l}\text { Resources } \\
\text { Rent }\end{array}$ & $-0.158 * * *$ & -0.00417 & -0.0373 & $0.0814 * *$ & $0.170 * * *$ & $0.145^{* * *}$ & 0.0167 & 0.0379 & 0.0211 \\
\hline & $(0.0520)$ & $(0.0505)$ & $(0.0561)$ & $(0.0410)$ & $(0.0437)$ & $(0.0450)$ & $(0.0384)$ & $(0.0384)$ & $(0.0383)$ \\
\hline Consumption & $\begin{array}{l}-0.0275 \\
(0.0328)\end{array}$ & $\begin{array}{l}0.128 * * * \\
(0.0307)\end{array}$ & $\begin{array}{l}0.120^{* * *} \\
(0.0342)\end{array}$ & $\begin{array}{c}0.0403 \\
(0.0297)\end{array}$ & $\begin{array}{c}0.0264 \\
(0.0325)\end{array}$ & $\begin{array}{c}0.0673 * * \\
(0.0328)\end{array}$ & $\begin{array}{c}0.0433 \\
(0.0265)\end{array}$ & $\begin{array}{c}0.0410 \\
(0.0271)\end{array}$ & $\begin{array}{c}0.0546 * * \\
(0.0264)\end{array}$ \\
\hline $\begin{array}{l}\text { Domestic } \\
\text { Credit }\end{array}$ & $-0.0806^{* * *}$ & $-0.0998^{* * *}$ & -0.0118 & $-0.0465 * * *$ & $-0.0765^{* * *}$ & 0.00192 & 0.00881 & 0.00881 & $0.0763^{* * *}$ \\
\hline $\begin{array}{l}\text { Trade } \\
\text { Freedom }\end{array}$ & $\begin{array}{c}(0.0132) \\
-0.0328\end{array}$ & $\begin{array}{c}(0.0126) \\
-0.152^{* * *}\end{array}$ & $\begin{array}{c}(0.0286) \\
-0.312^{* * *}\end{array}$ & $\begin{array}{l}(0.0141) \\
-0.00232\end{array}$ & $\begin{array}{c}(0.0152) \\
-0.0656^{* * *}\end{array}$ & $\begin{array}{c}(0.0295) \\
-0.0774 * * *\end{array}$ & $\begin{array}{l}(0.0131) \\
0.0429^{* *}\end{array}$ & $\begin{array}{l}(0.0135) \\
0.0342^{*}\end{array}$ & $\begin{array}{l}(0.0240) \\
0.0391^{* *}\end{array}$ \\
\hline GDP Growth & $\begin{array}{c}(0.0442) \\
-0.0967 \\
(0.101)\end{array}$ & $\begin{array}{c}(0.0390) \\
0.227^{* *} \\
(0.0983)\end{array}$ & $\begin{array}{c}(0.0409) \\
0.188^{*} \\
(0.109)\end{array}$ & $\begin{array}{c}(0.0203) \\
-0.0383 \\
(0.0359)\end{array}$ & $\begin{array}{c}(0.0210) \\
-0.0121 \\
(0.0388)\end{array}$ & $\begin{array}{c}(0.0213) \\
-0.00873 \\
(0.0396)\end{array}$ & $\begin{array}{c}(0.0189) \\
-0.0994 * * * \\
(0.0347)\end{array}$ & $\begin{array}{c}(0.0190) \\
-0.0976^{* * *} \\
(0.0351)\end{array}$ & $\begin{array}{c}(0.0189) \\
-0.103 * * * \\
(0.0348)\end{array}$ \\
\hline Constant & $\begin{array}{c}72.10^{* * *} \\
(3.751)\end{array}$ & $\begin{array}{c}73.26^{* * *} \\
(3.711)\end{array}$ & $\begin{array}{c}70.32^{* * *} \\
(4.124)\end{array}$ & $\begin{array}{c}81.79 * * * \\
(5.161)\end{array}$ & $\begin{array}{c}89.50 * * * \\
(5.670)\end{array}$ & $\begin{array}{c}79.59 * * * \\
(5.733)\end{array}$ & $\begin{array}{c}57.09 * * * \\
(4.972)\end{array}$ & $\begin{array}{c}56.09 * * * \\
(5.116)\end{array}$ & $\begin{array}{c}51.40^{* * *} \\
(4.844)\end{array}$ \\
\hline Observations & 650 & 650 & 650 & 650 & 650 & 650 & 650 & 650 & 650 \\
\hline R-squared & 0.456 & 0.470 & 0.345 & 0.446 & 0.352 & 0.323 & 0.578 & 0.570 & 0.577 \\
\hline $\begin{array}{l}\text { Number of } \\
\text { country }\end{array}$ & & & & 50 & 50 & 50 & 50 & 50 & 50 \\
\hline $\begin{array}{l}\text { Hausman } \\
\text { Test }\end{array}$ & & & & 0.0022 & 0.0018 & 0.0232 & 0.0000 & 0.0000 & 0.0009 \\
\hline Year Dummy & & & & No & No & No & Yes & Yes & Yes \\
\hline
\end{tabular}

Note: P-values of Hausman specification test are reported. Standard errors in parentheses; ***, **, * refer level of significance at $1 \%, 5 \%$ and $10 \%$.

For the control variable female labor force percentage of the total labor force, the study gets expected negative sign signifying that the higher the inclusion of female labor force in a country, the lower is the gender gap and the coefficient is statistically significant at $1 \%$ level. The coefficient of natural resources rents over GDP is also highly significant and has theoretically expected positive sign, meaning that the higher the natural resources rents, the higher the gender disparities. The positive sign of the coefficient of the control variable domestic consumption implies that the higher the household consumption in an economy, the higher is the Gll and all coefficients are economically significant in all cases but statistically significant only in the FE model with main explanatory variable access to loan facilities (column 6). The coefficient of domestic credit to private sectors appears to be statistically highly significant negative effects on GIl except it affects through access to loan facilities which is statistically insignificant and has no evidence of explanation at least $10 \%$ level. The coefficients of freedom to trade are negative and statistically strongly significant only when financial inclusion affects GII through access of people to bank branches and access to more loan facilities. In every instance and model, the coefficients of GDP growth are positive but statistically insignificant. Controlling year effect in the fixed effects models (Column 7-9) points out, there is no significant change in baseline results. Moreover, the effect of GDP growth is found highly significant indicating that GDP growth reduces gender inequality. 


\section{Robustness Test}

This part of the study is related to the test of the robustness of the findings obtained from the fixed effects estimations. The robustness test is split into following two sections:

\subsection{Robustness test using the alternative method of estimation and controlling endogeneity}

Modified Wald test and Pesaran CD test respectively find out the presence of group-wise heteroskedasticity and cross-sectional dependency in the fixed effects regression model results (Table 4). To overcome the potential problem of endogeneity, country-level heterogeneity, heteroskedasticity and serial autocorrelation in the fixed effects models, the study employs difference GMM estimation of dynamic panel data proposed by Arellano and Bond (1991). The Arellano and Bond estimator is fit for datasets with larger crosssections and few periods. This study follows Roodman (2009). The first difference of all the control variables are treated as standard instruments, and the first lag of GII and GDP growth serve as GMM-type instrument in our dynamic estimation. Table 4 illustrates the one step Arellano-Bond Dynamic Panel-Data Estimation results. The dynamic panel data estimation results suggest that all the coefficient of financial inclusion indicators is negative and significant indicating that more access to ATMs, bank branches and loan facilities lower the gender gap, hence, empower women. All findings are coinciding with the results of OLS and fixed-effects models (Table 3) only the variation is in the difference in the level of significance. A one percent increase of access to bank's ATMs, branches and loans cut down the gender inequality index by $2.334,3.319$ and 0.363 points respectively, on average in the short run, Ceteris Paribas. The estimates are statistically significant at 1,5 , and $10 \%$ level respectively. 
Table 4

Arellano-Bond dynamic panel data estimation results

\begin{tabular}{|c|c|c|c|}
\hline \multicolumn{4}{|c|}{ Dependent Variable: Gender Inequality Index (GII) } \\
\hline & (1) & $(2)$ & (3) \\
\hline VARIABLES & Panel diff-GMM & Panel diff-GMM & Panel diff-GMM \\
\hline \multirow[t]{2}{*}{ Access to ATMs } & $-2.334^{\star \star \star}$ & & \\
\hline & $(0.629)$ & & \\
\hline \multirow[t]{2}{*}{ Access to Branches } & & $-3.319 * *$ & \\
\hline & & $(1.354)$ & \\
\hline \multirow[t]{2}{*}{ Access to Loans } & & & $-0.363^{\star}$ \\
\hline & & & $(0.200)$ \\
\hline \multirow[t]{2}{*}{ Female Labor Force } & 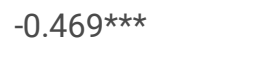 & 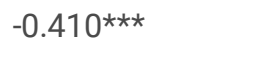 & 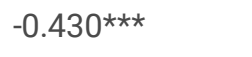 \\
\hline & $(0.130)$ & $(0.111)$ & $(0.135)$ \\
\hline \multirow[t]{2}{*}{ Resources Rent } & $0.200 * \star \star$ & 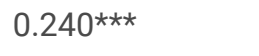 & $0.203^{\star * \star}$ \\
\hline & $(0.0652)$ & $(0.0751)$ & $(0.0611)$ \\
\hline \multirow[t]{2}{*}{ Consumption } & 0.0962 & 0.0941 & 0.111 \\
\hline & $(0.0649)$ & $(0.0674)$ & $(0.0695)$ \\
\hline \multirow[t]{2}{*}{ Domestic Credit } & 0.00927 & -0.00497 & -0.0198 \\
\hline & $(0.0116)$ & $(0.0123)$ & $(0.0170)$ \\
\hline \multirow[t]{2}{*}{ Trade Freedom } & 0.0255 & 0.0323 & $0.251^{*}$ \\
\hline & $(0.0204)$ & $(0.0234)$ & $(0.143)$ \\
\hline \multirow[t]{2}{*}{ GDP Growth } & $-0.0561^{\star \star \star}$ & $-0.0483^{\star \star \star}$ & $-0.0499 \star \star$ \\
\hline & $(0.0176)$ & $(0.0159)$ & $(0.0235)$ \\
\hline \multirow[t]{2}{*}{ L.GII } & $0.466^{\star \star \star}$ & $0.656^{\star \star \star}$ & $0.682^{\star \star \star}$ \\
\hline & $(0.109)$ & $(0.100)$ & $(0.115)$ \\
\hline Observations & 550 & 550 & 550 \\
\hline Number of country & 50 & 50 & 50 \\
\hline Instruments/Groups & $47 / 50$ & $47 / 50$ & $47 / 50$ \\
\hline \multicolumn{4}{|l|}{ Arellano-Bond test } \\
\hline $\operatorname{AR}(1)$ & 0.017 & 0.022 & 0.004 \\
\hline $\mathrm{AR}(2)$ & 0.910 & 0.604 & 0.365 \\
\hline Sargan test (Prob > chi2) & 0.253 & 0.185 & 0.301 \\
\hline Hansen test (Prob > chi2) & 0.195 & 0.261 & 0.355 \\
\hline \multicolumn{4}{|c|}{$\begin{array}{l}\text { Notes: (i) one step difference GMM with heteroscedasticity-consistent standard errors } \\
\text { (Arellano-Bond robust VCE estimator) and t-test statistics. } \\
\text { (ii) the instrument set is }(23) \text { and (iii) }{ }^{\star * *} p<0.01,{ }^{* \star} p<0.05 \text {, * } p<0.1\end{array}$} \\
\hline
\end{tabular}


The coefficient of female labor force and natural resources rent is also the same as the baseline results in fixed effects estimation with expected sign. The effects of these coefficients are strongly statistically significant at a $1 \%$ level which is similar to the level of significance in fixed-effects estimation. The study does not find any statistical significance of at least a $10 \%$ level to describe the coefficient of household consumption and domestic credit impacts on empowering women. But the coefficient of trade freedom is found a positive sign and statistically significant at the $10 \%$ level when the channel of the impact of financial inclusion is access to Ioan facilities by the people. In the fixed-effects model, the study found a negative and highly significant impact of trade freedom on GII. Economic growth measures by GDP growth rate are strongly significant at a $1 \%$ level and a negative sign is expected in all cases. The lag of dependent variable GII is also highly and positively significant indicating that the gender gap is persistent over the period and developing countries may face gender difference trap. A study on aid impact on gender inequality Pickbourn and Ndikumana (2016) also find a similar result. Unequal socio-cultural norms and structures regarding initial access to resources and economic opportunities are one of the main causes of persistent of the inequality trap.

GMM estimator has to satisfy several diagnostic checks including Sargan and Hansen test for instrument validity through overidentifying restrictions, and AR (1) and AR (2) tests for serial correlation. These test results are reported at the last three rows of Table 4 signifies that the study does not reject the null hypothesis of the validity of over-identifying restrictions, thus there is no indication of model misspecification in all specifications, and there is no evidence of first-order autocorrelation AR (1), but only in the second-order autocorrelation AR (2). These diagnostic tests confirming that in all models underlying assumptions for the selection of valid instruments are satisfied.

\subsection{Robustness test using the substitute dependent variables}

Table 5 Robustness test using the substitute dependent variables 
Table 5

Robustness test using the substitute dependent variables

\begin{tabular}{|c|c|c|c|c|c|c|}
\hline & (1) & (2) & (3) & (4) & (5) & (6) \\
\hline VARIABLES & GDI & GDI & GDI & $\begin{array}{l}\text { Political } \\
\text { Empowerment }\end{array}$ & $\begin{array}{l}\text { Political } \\
\text { Empowerment }\end{array}$ & $\begin{array}{l}\text { Political } \\
\text { Empowerment }\end{array}$ \\
\hline \multirow[t]{2}{*}{ Access to ATMs } & $1.456^{\star \star \star}$ & & & 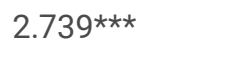 & & \\
\hline & $(0.123)$ & & & $(0.388)$ & & \\
\hline \multirow{2}{*}{$\begin{array}{l}\text { Access to } \\
\text { Branches }\end{array}$} & & $3.270 * \star \star$ & & & $5.342^{\star \star \star}$ & \\
\hline & & $(0.256)$ & & & $(0.826)$ & \\
\hline \multirow[t]{2}{*}{ Access to Loans } & & & $0.0867 * \star \star *$ & & & $0.291^{\star \star \star}$ \\
\hline & & & $(0.0228)$ & & & $(0.0674)$ \\
\hline \multirow{2}{*}{$\begin{array}{l}\text { Female Labor } \\
\text { Force }\end{array}$} & $0.475^{\star \star \star}$ & $0.492^{\star \star \star}$ & $0.448^{\star \star \star}$ & $1.032^{\star \star \star}$ & $1.063^{\star \star \star}$ & $0.926^{\star \star \star}$ \\
\hline & $(0.0675)$ & $(0.0665)$ & $(0.0748)$ & $(0.214)$ & $(0.215)$ & $(0.221)$ \\
\hline \multirow[t]{2}{*}{ Resources Rent } & $-0.0712^{\star \star \star}$ & 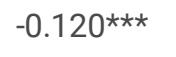 & $-0.109 * \star \star$ & 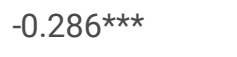 & 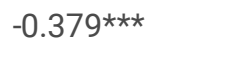 & 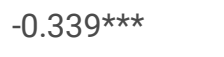 \\
\hline & $(0.0244)$ & $(0.0236)$ & $(0.0266)$ & $(0.0770)$ & $(0.0764)$ & $(0.0784)$ \\
\hline \multirow[t]{2}{*}{ Consumption } & $-0.0301^{*}$ & -0.00639 & $-0.0450 * \star$ & -0.0853 & -0.0500 & $-0.115^{\star \star}$ \\
\hline & $(0.0177)$ & $(0.0176)$ & $(0.0194)$ & $(0.0559)$ & $(0.0569)$ & $(0.0571)$ \\
\hline \multirow[t]{2}{*}{ Domestic Credit } & $0.0211^{\star \star}$ & $0.0189 * *$ & 0.00518 & $0.0753^{\star \star \star}$ & $0.0821^{\star \star \star}$ & -0.0404 \\
\hline & $(0.00836)$ & $(0.00822)$ & $(0.0174)$ & $(0.0264)$ & $(0.0266)$ & $(0.0515)$ \\
\hline \multirow[t]{2}{*}{ Trade Freedom } & $0.0470^{\star \star \star}$ & 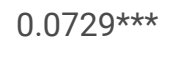 & $0.0898^{* \star *}$ & -0.0149 & 0.0393 & 0.0582 \\
\hline & $(0.0121)$ & $(0.0113)$ & $(0.0126)$ & $(0.0382)$ & $(0.0367)$ & $(0.0371)$ \\
\hline \multirow[t]{2}{*}{ GDP Growth } & 0.0152 & 0.00438 & -0.00189 & 0.0507 & 0.0282 & 0.0228 \\
\hline & $(0.0213)$ & $(0.0210)$ & $(0.0234)$ & $(0.0675)$ & $(0.0678)$ & $(0.0690)$ \\
\hline \multirow[t]{2}{*}{ Constant } & $67.68^{\star \star \star}$ & $60.41^{\star \star \star}$ & $68.66^{\star \star \star}$ & $-21.63^{\star \star}$ & -33.58 *ᄎ & $-17.91^{\star}$ \\
\hline & (3.066) & (3.068) & (3.386) & (9.698) & (9.916) & (9.991) \\
\hline Observations & 650 & 650 & 650 & 650 & 650 & 650 \\
\hline R-squared & 0.474 & 0.490 & 0.365 & 0.260 & 0.251 & 0.222 \\
\hline $\begin{array}{l}\text { Number of } \\
\text { country }\end{array}$ & 50 & 50 & 50 & 50 & 50 & 50 \\
\hline Hausman Test & 0.0029 & 0.0163 & 0.0236 & 0.0000 & 0.0001 & 0.0000 \\
\hline
\end{tabular}


Table 6

Sources of data

\begin{tabular}{|c|c|c|c|}
\hline Variables & Definition & Data source & URLS \\
\hline GII & Gender Inequality Index & $\begin{array}{l}\text { Human } \\
\text { Development } \\
\text { Reports, UNDP }\end{array}$ & http://hdr.undp.org/en/content/gender-inequality-index-gii \\
\hline GDI & Gender Development Index & $\begin{array}{l}\text { Human } \\
\text { Development } \\
\text { Reports, UNDP }\end{array}$ & $\begin{array}{l}\text { http://hdr.undp.org/en/content/gender-development- } \\
\text { index-gdi }\end{array}$ \\
\hline $\begin{array}{l}\text { Women } \\
\text { Political } \\
\text { Empowerment }\end{array}$ & $\begin{array}{l}\text { Proportion of seats held by } \\
\text { women in national } \\
\text { parliaments (\%) }\end{array}$ & $\begin{array}{l}\text { World } \\
\text { Development } \\
\text { Indicators (WDI) }\end{array}$ & https://data.worldbank.org/indicator/SG.GEN.PARL.ZS \\
\hline $\begin{array}{l}\text { Access to } \\
\text { ATMs }\end{array}$ & $\begin{array}{l}\text { Number of ATMs per } \\
100,000 \text { adults }\end{array}$ & $\begin{array}{l}\text { IMF Financial } \\
\text { Access Survey }\end{array}$ & $\begin{array}{l}\text { http://data.imf.org/?sk=E5DCAB7E-A5CA-4892-A6EA- } \\
\text { 598B5463A34C\&sld=1412015057755 }\end{array}$ \\
\hline $\begin{array}{l}\text { Access to Bank } \\
\text { Branches }\end{array}$ & $\begin{array}{l}\text { Number of branches per } \\
100,000 \text { adults }\end{array}$ & $\begin{array}{l}\text { IMF Financial } \\
\text { Access Survey }\end{array}$ & $\begin{array}{l}\text { http://data.imf.org/?sk=E5DCAB7E-A5CA-4892-A6EA- } \\
\text { 598B5463A34C\&sld=1412015057755 }\end{array}$ \\
\hline Access to loans & $\begin{array}{l}\text { Outstanding loans from } \\
\text { commercial banks (\% of } \\
\text { GDP) }\end{array}$ & $\begin{array}{l}\text { IMF Financial } \\
\text { Access Survey }\end{array}$ & $\begin{array}{l}\text { http://data.imf.org/?sk=E5DCAB7E-A5CA-4892-A6EA- } \\
\text { 598B5463A34C\&sld=1412015057755 }\end{array}$ \\
\hline $\begin{array}{l}\text { Female Labor } \\
\text { Forces }\end{array}$ & $\begin{array}{l}\text { Labor force, female (\% of } \\
\text { total labor force) }\end{array}$ & $\begin{array}{l}\text { World } \\
\text { Development } \\
\text { Indicators (WDI) }\end{array}$ & https://data.worldbank.org/indicator/SL.TLF.TOTL.FE.ZS \\
\hline $\begin{array}{l}\text { Natural } \\
\text { Resources Rent }\end{array}$ & $\begin{array}{l}\text { Total natural resources rents } \\
(\% \text { of GDP) }\end{array}$ & $\begin{array}{l}\text { World } \\
\text { Development } \\
\text { Indicators (WDI) }\end{array}$ & https://data.worldbank.org/indicator/NY.GDP.TOTL.RT.ZS \\
\hline Consumption & $\begin{array}{l}\text { Final consumption } \\
\text { expenditure (\% of GDP) }\end{array}$ & $\begin{array}{l}\text { World } \\
\text { Development } \\
\text { Indicators (WDI) }\end{array}$ & https://data.worldbank.org/indicator/NE.CON.TOTL.ZS \\
\hline $\begin{array}{l}\text { Domestic } \\
\text { Credit }\end{array}$ & $\begin{array}{l}\text { Domestic credit to private } \\
\text { sector (\% of GDP) }\end{array}$ & $\begin{array}{l}\text { World } \\
\text { Development } \\
\text { Indicators (WDI) }\end{array}$ & https://data.worldbank.org/indicator/FS.AST.PRVT.GD.ZS \\
\hline Trade Freedom & Trade Freedom Score & $\begin{array}{l}\text { The Heritage } \\
\text { Foundation }\end{array}$ & https://www.heritage.org/index/explore \\
\hline GDP Growth & GDP growth (annual \%) & $\begin{array}{l}\text { World } \\
\text { Development } \\
\text { Indicators (WDI) }\end{array}$ & https://data.worldbank.org/indicator/NY.GDP.MKTP.KD.ZG \\
\hline
\end{tabular}

Table 7

Test of multicolinearity

\begin{tabular}{|lllllllll|}
\hline Variable & VIF & 1/VIF & Variable & VIF & 1/VIF & Variable & VIF & $1 /$ VIF \\
\hline InATMs & 2.26 & 0.441921 & InBranches & 1.46 & 0.682979 & InLoans & 6.06 & 0.165056 \\
\hline CON & 1.97 & 0.5078 & CON & 1.77 & 0.565482 & CON & 1.77 & 0.564129 \\
\hline DC & 1.55 & 0.647158 & DC & 1.44 & 0.696305 & DC & 5.96 & 0.167683 \\
\hline GDP & 1.15 & 0.865859 & GDP & 1.12 & 0.896832 & GDP & 1.12 & 0.896022 \\
\hline LF & 1.27 & 0.786019 & LF & 1.52 & 0.660063 & LF & 1.43 & 0.70066 \\
\hline NRR & 1.58 & 0.633154 & NRR & 1.52 & 0.656326 & NRR & 1.52 & 0.656976 \\
\hline TF & 1.75 & 0.571464 & TF & 1.39 & 0.717622 & TF & 1.24 & 0.806576 \\
\hline Mean VIF & 1.65 & & Mean VIF & 1.46 & & Mean VIF & 2.73 & \\
\hline
\end{tabular}

Table 5 illustrates the results of the baseline model using fixed effects estimation techniques where the control variables are identical. Instead of our main dependent variable GII, the study uses GDI (Column 1-3) and political empowerment (column 4-6) as an 
independent variable. Moving from columns 1 to 6 , it is observed that the indicators of financial inclusion have strong positive effects on GDI and the political empowerment of women. All the results are as our expectation and statistically significant at a $1 \%$ level indicating that more geographical outreach of automated teller machines, commercial banks outlets and access to loan facilities not only help to improve the gender development but also enhance the political empowerment of females in the developing nations. These findings are in support of our baseline fixed effects model results (Table 5). The study does not find any statistically significant relationship to describe the impact of GDP on GDI and the political empowerment of females. But the addition of females to the total labor market has a strong positive relationship with both dependent variables. We find the freedom to execute international trade does not have significant positive effects on women's political empowerment but it significantly facilitates women empowerment by increasing of gender development index. As natural resources rent increases gender disparities, so the negative impact of this control is expected and significant at $1 \%$ level to GDI and political empowerment indicators. Therefore, the study can conclude that financial inclusion helps to diminish gender inequality, assists to improve gender development and empower women's political engagement.

\section{Conclusions}

This study brings to light the relationship between financial inclusion and women empowerment and contributes to the literature that more access to the financial premises and services reduces gender disparities, promotes women empowerment that would help developing countries to achieve SDGs, particularly SDG 5. This paper uses three indicators of financial inclusion such as access to ATMs, access to bank branches and access to loans from the Financial Access Survey, IMF database and tests the link between each of them and gender inequality index in fixed effects and difference generalized method of moment (GMM) specification for the balance panels of a total 50 developing countries over the period 2005-2017. The empirical results reveal that different indicators of financial inclusion have statistically significant and negative effects on the gender inequality index. These empirical findings are also robust using different alternative dependent variables and methods of estimation. The study uses the gender development index and political participation of women as the dependent variable and gets significant positive effects of financial inclusion. The difference generalized method of moment (GMM) estimation result confirms the robustness of the findings once again with controlling the country heterogeneity, autocorrelation, and endogeneity issue. Thus, financial inclusion reduces the gender gap; improve gender development and political empowerment of women. Targeting more women's involvement in access to the use of bank's ATMs, outlets and credit facilities can be an excellent strategy for women empowerment.

The important policy implication of this study is that developing countries are likely to obtain extensive benefits from the inclusion of more female people to banking channels towards achieving the SDGs. This also helps regulatory authorities and the government to set up an appropriate legal and regulatory framework in support of women-centric financial inclusion policies. Moreover, women targeted financial education programs, gender-responsive financial strategies, and customized product sales and promotion policies are effective strategies for women empowerment. This study would benefit from considering more gender-specific disaggregated data on financial inclusion which are currently not available for long-run impact analysis on women empowerment (Global Findex database of World Bank only consist of data for three years). The availability of disaggregated data would offer the possible scope for future empirical analysis in this field on both single country and cross-country perspective.

\section{Appendix}

\section{Appendix A: Sample Country List}

Albania, Algeria, Azerbaijan, Bangladesh, Benin, Bolivia, Botswana, Burundi, Cambodia, Cameroon, China, Colombia, Costa Rica, Dominican Republic, Ecuador, El Salvador, Georgia, Ghana, Guatemala, Honduras, India, Indonesia, Iran, Islamic Rep., Jamaica, Jordan, Kenya, Kyrgyz Republic, Malawi, Malaysia, Mauritius, Mexico, Moldova, Mongolia, Mozambique, Namibia, Nepal, Nicaragua, Niger, Pakistan, Peru, Philippines, Rwanda, Senegal, Serbia, South Africa, Thailand, Tunisia, Turkey, Uganda, Ukraine.

\section{Appendix B}

See Table 6

Table 6 Sources of data

Appendix C 
See Table 7

Table 7 Test of multicolinearity

\section{Declarations}

Ethics approval and consent to participate

Ethical approval and consent to participate is not applicable for this study.

\section{Consent for publication}

Not Applicable

\section{Availability of data and material}

The datasets used and/or analyzed during the current study are available from the corresponding author on reasonable request.

\section{Competing interests}

The authors declare that they have no competing interests.

\section{Funding}

This study did not receive any specific grant from funding agencies in the public, commercial or not-for-profit sectors.

\section{Authors' contributions}

All authors contributed equally to this work. All authors read and approved the final manuscript.

\section{Acknowledgements}

Not Applicable

\section{Authors' information (optional)}

Chandan Kumar Roy, PhD Candidate, School of International Trade and Economics, University of International Business and Economics, China and Deputy Director, Bangladesh Bank (The Central Bank of Bangladesh), Dhaka, Bangladesh. Email: chandan_hstu@yahoo.com

Banna Banik, Deputy Director, Bangladesh Bank, Department of Offsite Supervision, Head Office, Dhaka-1000, Bangladesh. E-Mail: banna.banik@yahoo.com

Huang Xiaoling, PhD, Professor of Economics, School of International Trade and Economics (SITE), University of International Business and Economics (UIBE), Beijing, China, Email: xlh_uibe@aliyun.com

Corresponding author: Chandan Kumar Roy, chandan_hstu@yahoo.com

\section{References}

1. AFI (2016) Policy Frameworks to Support Women's Financial Inclusion. AFI Special Report, Kuala Lumpur. https://www.afiglobal.org/sites/default/files/publications/2016-08/2016-02-womenfi.1_0.pdf

2. Alam S (2012) The Effect of Gender-Based Returns to Borrowing on Intra-Household Resource Allocation in Rural Bangladesh. World Dev 40(6):1164-1180. https://doi.org/10.1016/j.worlddev.2011.12.009

3. Arellano M, Bond S (1991) Some Tests of Specification for Panel Data: Monte Carlo Evidence and an Application to Employment Equations. The Review of Economic Studies 58(2):277-297. https://doi.org/10.2307/2297968

4. Armendáriz B, Morduch J (2010) The Economics of Microfi nance. MIT Press, London 
5. Ashraf N, Karlan D, Yin W (2010) Female Empowerment: Impact of a Commitment Savings Product in the Philippines. World Dev 38(3):333-344. https://doi.org/10.1016/j.worlddev.2009.05.010

6. Beck T, Demirgüç-Kunt A, Levine R (2007) Finance, inequality and the poor. J Econ Growth 12(1):27-49. https://doi.org/10.1007/s10887-007-9010-6

7. Castilla C, Walker T (2013) Is Ignorance Bliss? The Effect of Asymmetric Information between Spouses on Intra-household Allocations. Am Econ Rev 103(3):263-268. https://doi.org/10.1257/aer.103.3.263

8. Cheston S, Kuhn L (2020) Empowering Women through Microfinance. http://chs.ubc.ca/srilanka/PDFs/Empowering\%20women\%20through\%20microfinance.pdf

9. Cull R, Demirgüç-Kunt A, Lyman T (2012) Financial Inclusion and Stability: What Does Research Show? World Bank Other Operational Studies 9443, The World Bank. https://ideas.repec.org/p/wbk/wboper/9443.html

10. Demirgüç-Kunt A, Klapper L, Singer D, Ansar S, Hess J (2018) The Global Findex Database 2017: measuring fnancial inclusion and the fntech revolution. World Bank Group, Washington, DC. http://documents.worldbank.org/curat ed/en/332881525873182837/pdf/126033-PUB-PUBLIC-pubdate-4-19-2018.pdf

11. Dupas P, Robinson J (2013) Why Don't the Poor Save More? Evidence from Heath Savings Experiments. Am Econ Rev 103(4):1138-1171. http://dx.doi.org/10.1257/aer.103.4.1138

12. IFC (2016) Research and Literature Review of Challenges to Women Accessing Digital Financial Services. International Finance Corporation Publication, Washington DC https://www.ifc.org/wps/wcm/connect/a898cd03-6ce9-46da-a45a31ed33e62077/Research+and+Lit+Review+of+Challenges+to+Women+Accessing+DFS.pdf?MOD=AJPERES\&CVID=INGfhTk

13. IMF (2018) Pursuing women economic empowerment. Meeting of G7 Ministers and Central Bank Governors, June 1-2, 2018 Whistler, Canada. https://www.imf.org/ /media/Files/Publications/PP/2018/pp053118pursuing-womens-economicempowerment.ashx

14. Isaac J (2014) Expanding Women's Access to Financial Services. https://www.worldbank.org/en/results/2013/04/01/banking-onwomen-extending-womens-access-to-financial-services. Accessed 10 Oct 2019

15. Hair JF Jr, Black WC, Babin BJ, Anderson RE (2010) Multivariate data analysis, 7th edn. Pearson, Essex

16. Kabeer N (2005) Is Microfinance a 'Magic Bullet' for Women's Empowerment? Analysis of Findings from South Asia. Economic Political Weekly 40(44/45):4709-4718

17. Khandker SR (2005) Microfinance and Poverty: Evidence Using Panel Data from Bangladesh. The World Bank Economic Review 19(2):263-286. http://hdl.handle.net/10986/16478

18. Kim J (2016) A Study on the Effect of Financial Inclusion on the Relationship Between Income Inequality and Economic Growth. Emerging Markets Finance Trade 52(2):498-512. https://doi.org/10.1080/1540496X.2016.1110467

19. Kim DW, Yu JS, Kabir HM (2018) Financial inclusion and economic growth in OIC countries'. Research in International Business Finance 43(C):1-14. https://doi.org/10.1016/j.ribaf.2017.07.178

20. Kpodar KR, Andrianaivo M (2011) ICT, Financial Inclusion, and Growth; Evidence from African Countries. IMF Working Papers 11/73, International Monetary Fund (2011). https://www.imf.org/external/pubs/ft/wp/2011/wp1173.pdf

21. Mahmood S (2011) Microfinance and women entrepreneurs in Pakistan. International Journal of Gender Entrepreneurship 3(3):265-274. https://doi.org/10.1108/17566261111169340

22. Nwafor MC, Yomi Al (2018) The Nexus between Financial Inclusion and Economic Growth: Evidence from Nigeria. International Journal of Research and Innovation in Social Science II(IV): 143-149. https://www.rsisinternational.org/journals/ijriss/DigitalLibrary/volume-2-issue-4/143-149.pdf?x49905

23. Onaolapo AR (2015) Effects of Financial Inclusion on the Economic Growth of Nigeria. International Journal of Business Management Review 3(8):11-28. http://www.eajournals.org/wp-content/uploads/Effects-of-Financial-Inclusion-on-the-EconomicGrowth-of-Nigeria-1982-2012.pdf

24. Pickbourn L, Ndikumana L (2016) The Impact of Sectoral Allocation of Foreign Aid on Gender Inequality. J Int Dev 28(3):396-411. https://doi.org/10.1002/jid.3213

25. Pitt MM, Khandker SR, Cartwright J (2006) Empowering Women with Micro Finance: Evidence from Bangladesh. Econ Dev Cult Change 54(4):791-831. https://doi.org/10.1086/503580

26. Roodman D (2009) How to Do xtabond2: An Introduction to "Difference" and "System" GMM in Stata. Stata Journal 9(1):86-136. https://doi.org/10.1177/1536867X0900900106 
27. Sahay R, Cihak M, N'Diaye PM, Barajas A, Mitra S, Kyobe A, Mooi YN, Yousef SR (2015) Financial inclusion: can it meet multiple macroeconomic goals? IMF Staf Discussion Notes 15/17, International Monetary Fund. https://www.

imf.org/external/pubs/ft/sdn/2015/sdn1517.pdf

28. Sharma D (2016) Nexus between financial inclusion and economic growth. Journal of Financial Economic Policy 8(1):13-36. https://doi.org/10.1108/JFEP-01-2015-0004

29. Swain RB, Wallentin FY (2009) Does microfinance empower women? Evidence from self-help groups in India. Int Rev Appl Econ 23(5):541-556. https://doi.org/10.1080/02692170903007540

30. Tang H, Zhang Y (2014) Cross-Country Diffusion of Culture through FDI: A Firm-Level Analysis of Gender Inequality in China. https://pdfs.semanticscholar.org/badc/509105a0bf601b5e2d117c380aa80ac89207.pdf

31. World Bank/OECD (2013) Women and Finance: Progress Report to the G20, [Online], Available: https://financialallianceforwomen.org/download/g20-women-finance-report/. Accessed 15 Dec 2018

32. Zhang Q, Posso A (2019) Thinking Inside the Box: A Closer Look at Financial Inclusion and Household Income. Journal of Development Studies 55(7):1616-1631. https://doi.org/10.1080/00220388.2017.1380798

\section{Figures}

Correlation coefficient: -5.398903

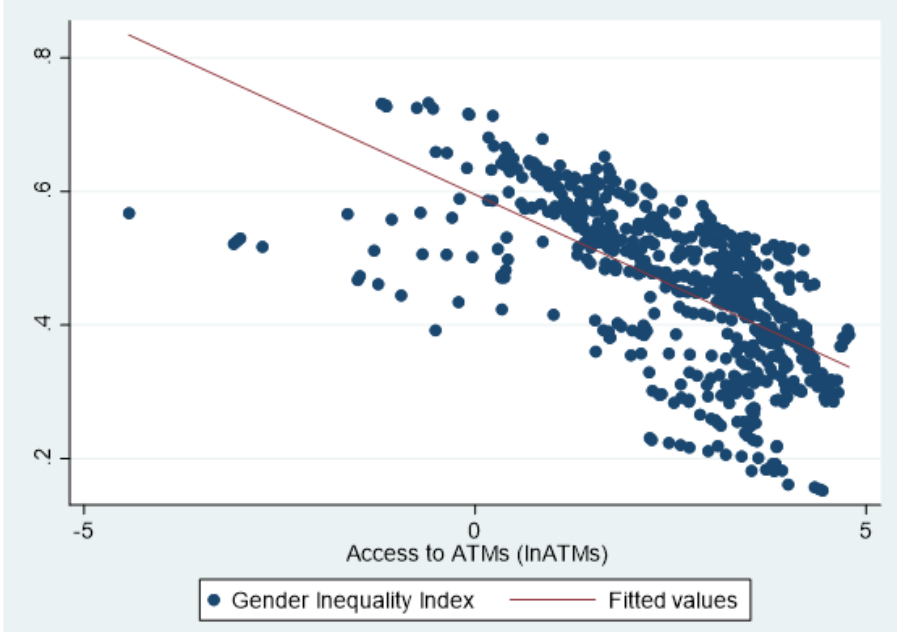

Source: FAS, IMF and UNDP Database; Author's Calculation
Correlation coefficient: 2.917568

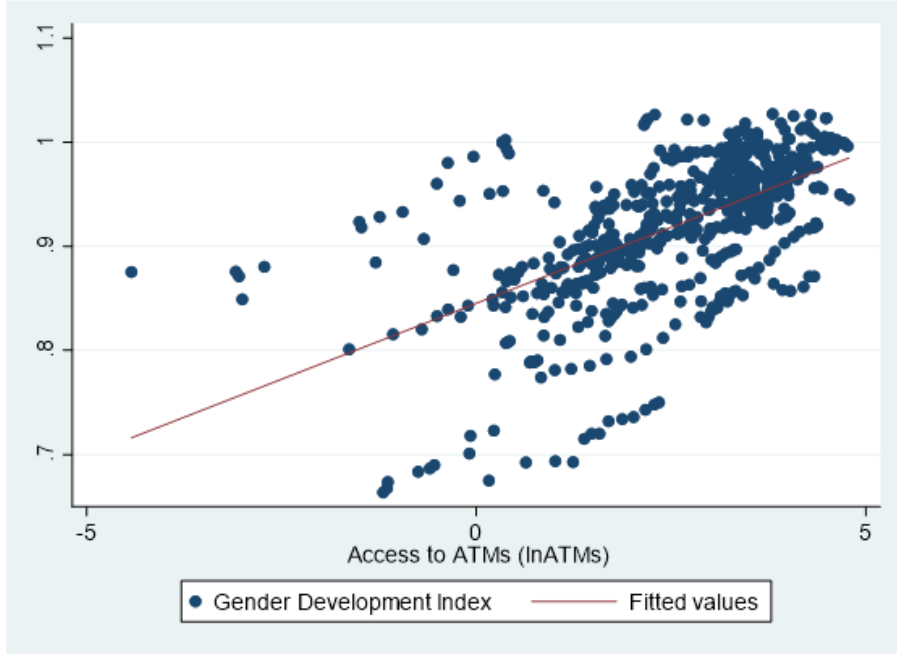

\section{Figure 1}

FI (access to ATMs), GII and GDI, 2005-2017 
Correlation coefficient: -6.841443

R-sq: 0.2896

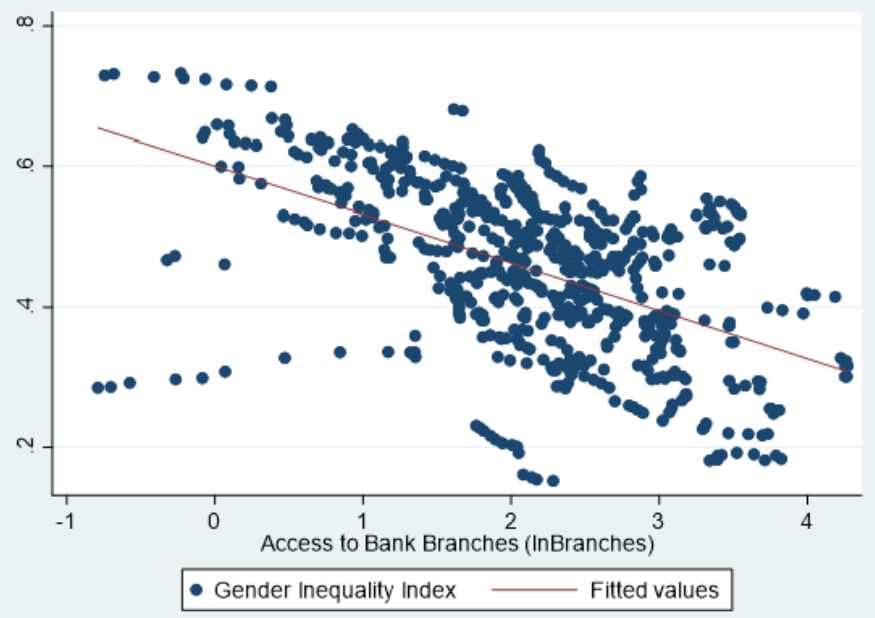

Source: FAS, IMF and UNDP Database; Author's Calculation

\section{Figure 2}

FI (access to bank branches), GII and GDI, 2005-2017

Correlation coefficient: -0.2705346

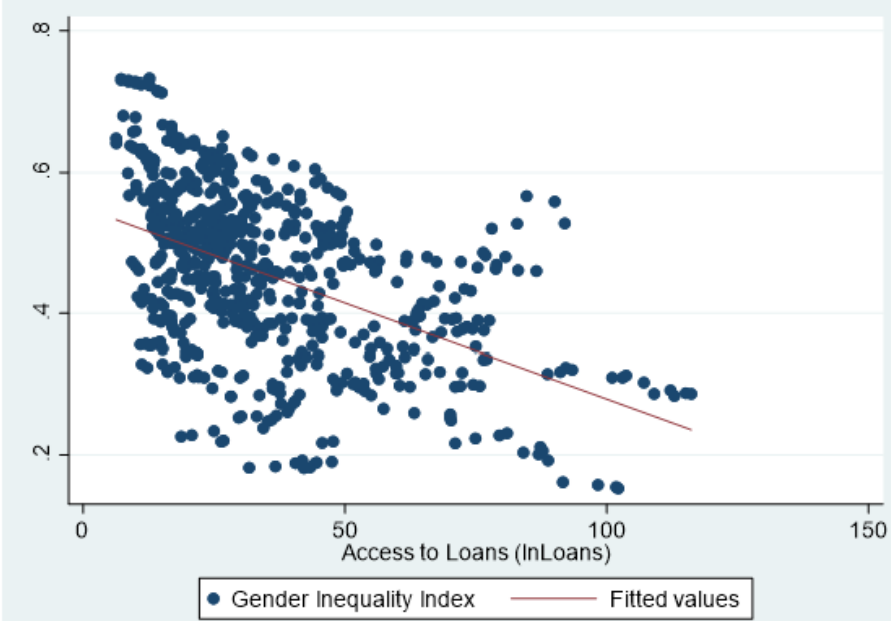

Source: FAS, IMF and UNDP Database; Author's Calculation
Correlation coefficient: 3.043424

R-sq: 0.1731

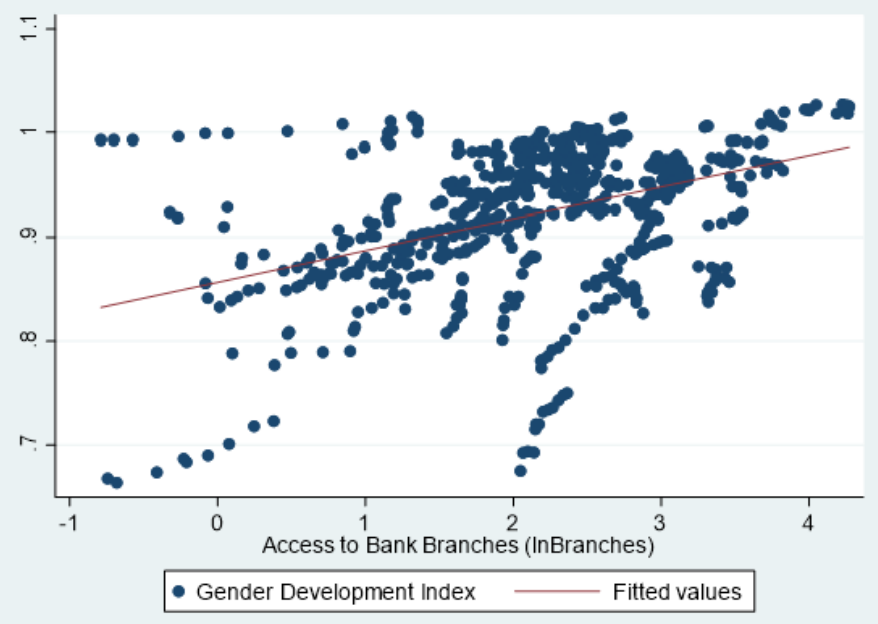

Correlation coefficient: 0.0719023

R-sq: 0.0529

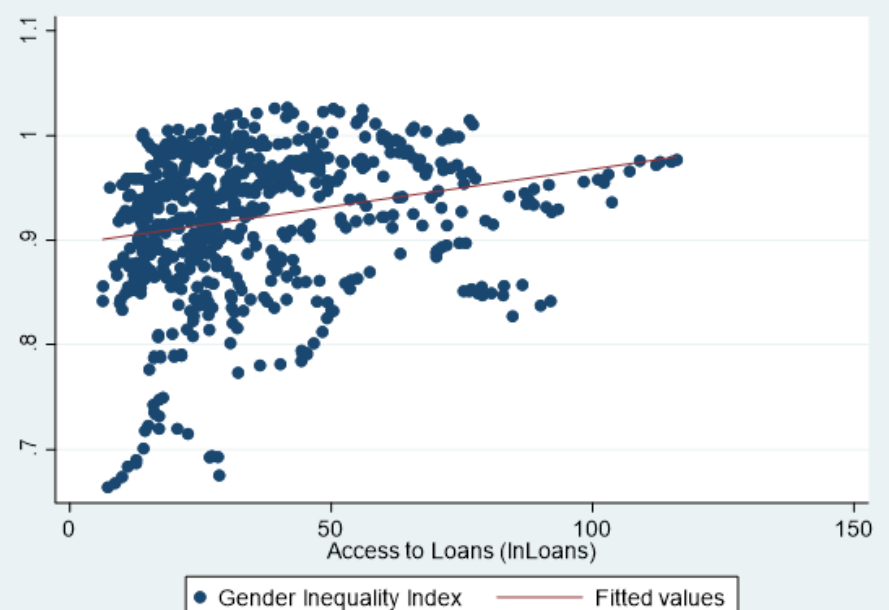

Figure 3

FI (access to loans), GII and GDI, 2005-2017 